\title{
Normatif Review terhadap Tanggung Jawab Pemerintah Daerah dalam Menjaga Kualitas Air dan Mencegah Pencemaran Air
}

\author{
Stevri Iskandar ${ }^{1}$ \\ Siska Iskandar ${ }^{2}$ \\ ${ }^{1}$ Fakultas Hukum Universitas Bengkulu \\ ${ }^{2}$ Akkes Sapta Bakti Bengkulu \\ Email Korespondensi : st.iskandar@unib.ac.id
}

\begin{abstract}
The purpose of this research is to see the responsibility of local governments in maintaining water quality and preventing water pollution. This research is a normative study, the primary legal materials used as a research source include all laws and regulations governing irrigation/water resources (internal review), secondary legal materials used include all publications on law textbooks, legal dictionaries, legal journals. , legal seminar proceedings, interview results that have been written in the form of a report. As a complement to this research, also use non-legal materials in the form of environmental research reports, RKL-RPL, forestry, non-legal journals that have relevance to the object of study. The results of this study indicate that the basis for the authority of the Lebong Regency Regional Government in regulating the feasibility test for river water classes in Lebong Regency is based on the authority to carry out concurrent government affairs in the environmental sector as regulated in Article 12 of Law Number 23 of 2014 concerning Regional Government, and the mandate of the Law. Law Number 32 the Year 2009 concerning Environmental Protection and Management, as well as the mandate of Government Regulation Number 82 the Year 2001 concerning Water Quality Management, namely mandating the preparation of a water utilization plan; monitoring water quality at water sources; determine the water quality status; and set the water class.
\end{abstract}

Keywords : Local government; Water pollution; Water quality.

\begin{abstract}
ABSTRAK
Tujuan penelitian ini untuk melihat tanggungjawab pemerintah daerah dalam menjaga kualitas air dan mencegah pencemaran air. Penelitian ini merupakan penelitian normatif, bahan hukum primer yang digunakan sebagai sumber penelitian meliputi semua peraturan perundang-undangan yang mengatur pengairan/sumber daya air (internal review), Bahan hukum sekunder yang digunakan meliputi semua publikasi tentang hukum buku teks, kamus hukum, jurnal hukum, prosiding seminar hukum, hasil wawancara yang sudah ditulis dalam bentuk laporan Sebagai pelengkap penelitian ini juga menggunakan bahan-bahan non hukum berupa laporan penelitian lingkungan hidup RKL-RPL, kehutanan, jurnal non hukum yang mempunyai relevansi dengan objek kajian. Hasil penelitian ini bahwa Landasan kewenangan Pemerintah Daerah Kabupaten Lebong dalam mengatur uji kelayakan kelas air sungai di Kabupaten Lebong didasarkan atas kewenangan dalam melaksanakan urusan pemerintahan konkuren bidang lingkungan hidup yang diatur dalam Pasal 12 Undang-Undang Nomor 23 Tahun 2014 tentang Pemerintahan Daerah, dan amanat Undang-Undang Nomor 32 Tahun 2009 tentang Perlindungan dan Pengelolaan Lingkungan Hidup, serta amanat Peraturan Pemerintah Nomor 82 Tahun 2001 tentang Pengelolaan Kualitas Air yaitu amanat melakukan penyusunan rencana pendayagunaan air; pemantauan kualitas air pada sumber-sumber air; menetapkan status mutu air; dan menetapkan kelas air.
\end{abstract}

Kata kunci : Kualitas air; Pemerintah daerah; Pencemaran air. 


\section{Pendahuluan}

Air merupakan sumber daya alam yang memenuhi hajat hidup orang banyak sehingga perlu dilindungi agar dapat tetap bermanfaat bagi hidup dan kehidupan manusia serta makhluk hidup lainnya. Untuk menjaga atau mencapai kualitas air sehingga dapat dimanfaatkan secara berkelanjutan sesuai dengan tingkat mutu air yang diinginkan, maka perlu upaya pelestarian dan atau pengendalian.

Pelestarian kualitas air merupakan upaya untuk memelihara fungsi air agar kualitasnya tetap pada kondisi alamiah. Air sebagai komponen lingkungan hidup akan mempengaruhi dan dipengaruhi oleh kompenen lainnya. Air yang kualitasnya buruk akan mengakibatkan kondisi lingkungan hidup akan menjadi buruk pula, sehingga akan mempengaruhi kondisi kesehatan dan keselamatan manusia serta kehidupan mahluk hidup lainnya.

Selain itu, konsistensi pengawasan lingkungan hidup daerah pasca berlakunya Perda $a$ quo, akan memberi dampak positif yang bernilai ekonomis, yakni terjadinya pertumbuhan ekonomi, dari sektor usaha ekonomi masyarakat yang berbasis air. Hal ini sesuai dengan fungsi air itu sendiri yang dapat dimanfaatkan untuk berbagai usaha dan/atau kegiatan manusia memerlukan air yang berdaya guna, seperti perikanan budidaya, pertanian (sawah), industri perhotelan, pariwisata (arung jeram, danau), dan sebagainya. Namun air juga berpotensi menimbulkan dampak negatif, antara lain berupa pencemaran yang dapat mengancam ketersediaan air, daya guna, daya dukung, daya tampung dan produktivitasnya. Agar air dapat bermanfaat secara lestari dan pembangunan dapat berkelanjutan, maka dalam pelaksanaan pembangunan perlu dilakukan pengelolaan kualitas air dan pengendalian pencemaran air yang benar dan berpedoman kepada baku mutu air dan sesuai dengan kelas airnya di Kabupaten Lebong.

Kabupaten Lebong merupakan salah satu daerah otonom dalam wilayah Provinsi Bengkulu yang dibentuk berdasarkan Undang-Undang Nomor 39 Tahun 2003 tentang Pembentukan Kabupaten Lebong dan Kabupaten Kepahiang di Provinsi Bengkulu.

Sebagai sebuah daerah otonom baru, Kabupaten Lebong memiliki potensi sumberdaya alam yang sangat besar sektor energi berbasis air dan panas bumi, serta pertambangan antara lain emas dan batubara. Bahkan sektor pertambangan dan energi panas bumi menjadi salah satu sektor yang diharapkan dapat menunjang perekonomian masyarakat dan pendapatan daerah terutama dalam menunjang pengentasan kemiskinan di Kabupaten Lebong.

Dinas Lingkungan Hidup Kabupaten Lebong sendiri memperkirakan pada saat kegiatan pertambangan memasuki masa konstruksi “diperkirakan dapat menurunkan kualitas air 
permukaan, sehingga lebih lanjut berdampak terhadap kehidupan biota air yang terdapat di dalam badan perairan"1 sekitar pertambangan.

Hasil pengujian kualitas air lainnya pada proyek pembangunan lapangan panas bumi PT.Geothermal Energy, menyimpulkan kualitas air permukaan sungai bervariasi di lingkungan pengembangan lapangan uap panas bumi dan PLTP Hululais, yang menunjukkan kualitas air kritis (critical level) di mana TSS, BOD $5, \mathrm{COD}, \mathrm{pH}$, koliform total, boron dan seng yang melebihi baku mutu yang ditetapkan dalam Peraturan Pemerintah Nomor 82 Tahun 2001 tentang Pengelolaan Kualitas Air dan Pengendalian Pencermaran Air, terhadap air kelas II, terjadi pada Air Kotok Hulu, Air Koto Hilir, Air Siamang, Air WPS Cluster E dan Danau Macan II. ${ }^{2}$ Namun untuk kualitas air tanah (sumur penduduk) di Kelurahan Taba Anyar dan Desa Danau Liang yang dilakukan pada waktu yang sama tergolong layak sebagai air minum, sesuai dengan parameter kalitas air sumur, tidak ada yang melebihi nilai baku mutu air minum yang ditetapkan dalam Permenkes Nomor 416/MENKES/PER/IX/1990. ${ }^{3}$

Terlepas dari hasil pengujian yang sudah dilakukan dan menunjukkan rata-rata kualitas air belum tercemar berat, yang harus diantisipasi oleh Pemerintah Kabupaten Lebong melalui fungsi pengayoman adalah memberikan jaminan perlindungan hukum bagi masyarakat Kabupaten Lebong. Berdasarkan latar belakang di atas, tulisan ini bertujuan untuk melakukan normatif review terhadap tanggung jawab pemerintah daerah dalam menjaga kualitas air dan mencegah pencemaran air

\section{Metode Penelitian}

Penelitian ini merupakan penelitian normatif. Bahan hukum primer yang digunakan sebagai sumber penelitian meliputi semua peraturan perundang-undangan yang mengatur pengairan/sumber daya air (internal review), dan semua peraturan perundang-undangan terkait meskipun tidak mengatur lingkungan hidup, pengairan/sumber daya air, namun secara tidak langsung memiliki keterkaitan (eksternal review). Bahan hukum sekunder yang digunakan meliputi semua publikasi tentang hukum, terkhusus hukum lingkungan, hukum tata ruang, hukum sumber daya air, yang ditemukan dalam buku teks, kamus hukum, jurnal hukum, prosiding seminar hukum, hasil wawancara yang sudah ditulis dalam bentuk laporan, dan sebagainya yang relevan terhadap issue hukum yang menjadi objek kajian. Sebagai

\footnotetext{
${ }^{1}$ PT.Tansri Madjid Energi (Gold Mining Project). Laporan Pelaksanaan Pengelolaan Lingkungan Hidup Triwulan I, Maret 2018. h.37

${ }^{2}$ PT. Pertamina Geothermal Energy. Laporan Implementasi RKL-RPL Pengembangan Lapangan Uap Panas dan PLTP Hululais di Kecamatan Lebong Tengah dan Lebong Selatan Kabupaten Lebong, Priode Triwulan I Tahun 2018, h.III-1-2

${ }^{3} I b i d$, h.III-1-2.
} 
pelengkap penelitian ini juga menggunakan bahan-bahan non hukum berupa laporan penelitian lingkungan hidup RKL-RPL, kehutanan, jurnal non hukum yang mempunyai relevansi dengan objek kajian. Analisis bahan hukum dilakukan dengan menggunakan metode penalaran analogikal, baik analogi doktrin hukum maupun analogi preseden. ${ }^{4}$

\section{Analisis dan Pembahasan}

\section{Fakta empiris hasil pengujian kualitas air sungai di sekitar beberapa perusahaan DI}

\section{Kabupaten Lebong}

a. PT. Tansir Madjid Energi: ${ }^{5}$

Pemilik Izin Usaha Pertambangan operasi produksi berdasarkan SK Bupati Lebong Nomor 125 Tahun 2010 yang berlaku selama 20 tahun sampai dengan tahun 2028 yang berlokasi di Kecamatan Lebong Utara, Pinang Belapis dan Lebong Atas Kabupaten Lebong dengan luas area pada IUP operasi produksi adalah 8.191 hektar.

Sungai sekitar Air Selikat dan anak sungai Selikat, dan Air Sarang di Desa Tambang Sawah, dan Air Asam Tambang di Desa Lebong Tambang. Dampak pertambangan emas terhadap kualitas air yang dikelola berupa fisik air (padatan tersuspensi air (TTS), patan terlarut air (TDS), kekeruhan air; dan kimia air (keasaman air (pH air), kandungan logam-logam $\mathrm{Cu}$ (tembaga), $\mathrm{Cd}$ (cadmium), $\mathrm{Zn}$ (seng), $\mathrm{Pb}$ (timbal), As (arsen), Ni, Cr (total chromium), Sianida (CN) dan air raksa (Hg). Sumber dampak berasal dari:

a) Air limbah domestik. Pada tahap prakonstruksi, perubahan kualitas air diperkirakan berasal dari air limbah domestik yang dihasilkan permukiman tenaga kerja tambang. Besaran perubahan kualitas air tergantung jumlah tenaga kerja yang bermukim di base camp.

b) Air larian. Sumber lain perubahan kualitas air berasal dari air larian yang membawa partikel.

c) Air limbah pengolahan emas. Air limbah pengolahan emas hanya dihasilkan pada tahap operasi tambang. Sumber dampak berasal dari air limbah pengolahan emas secara kimia/sianidasi. Di Desa Tambang Sawah, pengolahan emas dilakukan secara kimia (sianidasi). Air dalam kolam yang mengandung sianida kemudian diolah

\footnotetext{
${ }^{4}$ Bahder Johan Nasution. 2008. Metode Penelitian Hukum. Bandung: Mandar Maju, h. 119.

${ }^{5}$ PT. Tansri Madjid Energi. Gold Mining Project. Laporan Pelaksanaan Pengelolaan Lingkungan Hidup Triwulan Ke-1, Lebong, Maret 2018, h.13-30
} 
dalam kolam detoksifikasi untuk mengendalikan sianida yang terlarut dalam air pada rendaman bijih emas.

Hasil pemantauan baku mutu air yang dilakukan Dinas Lingkungan Hidup Kabupaten Lebong menunjukkan:

1) Air Asam Tambang Lokasi Tambang Sawah

Pada analisa sampel air di okasi ini diperoleh hasil kandungan TSS sebesar $150 \mathrm{mg} / \mathrm{L}$ dibandingkan dengan baku mutu yang telah ditetapkan sebear 200mg/L sehingga hasil analisa laboratorium untuk parameter ini sesuai dengan baku mutu lingkungan yang telah ditetapkan.

2) Aliran Drainase Dekat Kolam Pengolahan

Pada analisia sampel air di okasi ini diperoleh hasil kandungan TSS sebesar 85,4 mg/L dibandingkan dengan baku mutu yang telah ditetapkan sebesar 200mg/L sehingga hasil analisa labratorium untuk parameter ini sesuai dengan baku mutu lingkungan yang telah ditetapkan.

3) Anak Sungai Selikat

Pada analisa sumber air di lokasi ini diperoleh hasil kandungan TSS sebesar 13,2 mg/L dibandingkan dengan baku mutu yang telah ditetapkan sebesar 200mg/L sehingga hasil analisas laboratorium untuk parameter ini sesuai dengan baku mutu lingkungan yang tetap ditetapkan.

4) Sungai Serikat Besar

Pada analisa sampel air di lokasi ini diperoleh hasil kandungan TSS sebesar 12,4 mg/L dengan baku mutu yang telah ditetapkan sebesar 200mg/L sehingga hasil analisa laboratorium untuk parameter ini sesuai dengan baku mutu lingkungan yang tetap ditetapkan.

Hasil uji laboratorium PT.Tansri Madjid Energi pada baku mutu air Asam Tambang desa Tambang Sawah, anak sungai Selikat, sungai Selikat Besar, dari sumber pencemar yang diuji meliputi TSS, unsur Zn (seng), Cd (cadmium), Hg (air raksa), Pb (timbal) As (arsen), Cn (sianda), Cu (tembaga) dan Cr (Total chromium), menunjukkan belum terjadi pencemaran baku mutu air, artinya baku mutu air masih berada di bawah ambang batas baku mutu lingkungan yang sudah ditetapkan dalam peraturan perundang-undangan. 


\section{b. PT. Jambi Resources: ${ }^{6}$}

PT. Jambi Resources merupakan salah satu perusahaan pertambangan batubara pemegang izin usaha pertambangan operasi produksi sesuai SK Bupati Lebong Nomor 212 Tahun 2013, pemegang KP Ekploitasi KW 001.K.L.08 tertanggal 27 Mei 2013 dengan luas wilayah 535 hektar. Secara administratif berlokasi di Desa Ketenong II Kecamatan Pinang Belapis Kabupaten Lebong Provinsi Bengkulu.

Sungai sekitar perusahaaan Air Tamang Desa Ketenong. Dampak pertambangan batubara terhadap kualitas air yang dikelola berupa $\mathrm{pH}$ (derajat keasaman), TSS (residu tersuspensi), Fe (besi total), Mn (mangaan total), SO4 (Sulfat), BOD5 dan COD.

Hasil pemantauan lingkungan (uji kelayakan/baku mutu air) di wilayah kerja perusahaan menunjukkan secara umum kondisi lingkungan terpelihara dengan baik, dengan pedoman baku mutu lingkungan yang ditetapkan dalam Peraturan Gubernur Provinsi Bengkulu Nomor 92 Tahun 2001 tentang Penetapan Baku Mutu Limbah Cair Kegiatan Industri Pertambangan Batu Bara yang beroperasi di wilayah Provinsi Bengkulu.

\section{c. PT. PLN (Persero) Pembangkit Sumbagsel Sektor Pembangkitan Bengkulu-Unit PLTA TES: ${ }^{7}$}

Secara geografis PLTA Tes terletak di daerah perbukitan pada $3^{0} 16$ LU dan $102^{0}$ 25BT yang dikelilingi jajaran pegunungan Bukit Barisan dengan cadagan air yang cukup besar. Terletak di Desa Turan Tiging Kecamatan Lebong Selatan. Kabupaten Lebong Provinsi Bengkulu.

PLTA Tes terdiri atas dua sentral unit, yang pertama adalah unit PLTA Tes Lama yang dibangun tahun 1912-1923 oleh kolonial Belanda dan beroperasi tahun 1923 di Desa Turan Tiging Kabupaten Rejang Lebong (sekarang Kabupaten Lebong), dengan 7 mesin pembangkit total menghasilkan $23.370 \mathrm{~kW}$. Saat ini daya yang dibangkitkan oleh PLTA Tes digunakan untuk memenuhi kebutuhan lisrik di Provinsi Bengkulu melalui jaringan $70 \mathrm{kV}$. Bahan baku PLTA disuplai dari danau Tes kemudian air dialirkan ke turbin melalui saluran terbuka sepanjang 1.850 meter.

\footnotetext{
${ }^{6}$ PT.Jambi Resources. Laporan Pelaksanaan Izin Lingkungan Kegiatan Penambangan Batubara Triwulan I Januari-Maret 2017. KP.KW 001 K.L.08 Desa Ketenong II, Keamatan Pidang Belapis, Lebong Provinsi Bengkulu, Tahun 2017, h.

${ }^{7}$ PT. PLN (Persero) Pembangkitan Sumbagsel Unit PLTA TES. Rencana Pengelolaan Lingkungan dan Rencana Pemantauan Lingkungan (RKL-RPL) Laporan Triwulan I Maret 2018, h. 1-3.
} 
Sungai sekitar perusahaan PT.PLN Pembangkit PLTA Tes meliputi sungai Ketahun Desa Tik Kuto, sungai Ketahun Desa Rimbo Pengadang, sungai Ketahun desa Tapus, sungai Ketahun desa Talang Ratu. Dampak lingkungan terhadap kualitas air sungai sekitar berupa suhu air, TSS (residu padatan tersuspensi), DTS (padatan terlarut), kekeruhan, daya hantar listrik, pH, Fe (besi total), BOD5 dan COD.

\section{d. PT. Pertamina Geothermal Energy (PGE)}

Kegiatan pengembangan lapangan uap panas bumi Hululais secara administrasi terletak di wilayah Kecamatan Lebong Selatan Kabupaten Lebong. Lokasi proyek in ditetapkan berdasarkan Surat Keputusan Menteri Energi dan Sumber Daya Mineral Nomor 2067K/30/MEN/2012 tentang Pemberian Wilayah Kuasa Pengusahaan (WKP) Sumber Daya Panas Bumi seluas 289.300 hektar kepada PT. Pertamina Geothermal Energy (PGE). WKP ini mencakup wiayah Provinsi Bengkulu dan Provinsi Sumatera Selatan dengan salah satu wilayah prospek adalah lapangan uap panas bumi Hululais. ${ }^{8}$

Status pekerjaan pengembangan lapangan uap panas bumi Hululais saat ini dalam tahap pemboran eksplorasi dan uji produksi sumur dengan tujuan untuk memperoleh kepastian yang lebih pasti mengenai dimensi reservoir dan besarnya cadangan terbukti.

Berdasarkan tata ruang wilayah Kabupaten Lebong, pengembangan sumberdaya panas bumi di lapangan Hululasis seagia areal kegiatan berada di Kawasan Hutan Lindung Bukit Gedang dan Hululais serta sebagian berada di wilayah areal peruntukan lain. $^{9}$

Sungai yang ada di sekitar atau berpotensi terdampak akibat pengembangan lapangan uap panas bumi Hululais meliputi sungai Air Kotok Hulu, Air Kotok Hilir, Air Siamang, Sungai Danau Macan II, sungai Air Karat Hulu, sungai Air Mubai Hulu.

Hasil pengujian bakumutu air terdampak kegiatan pengeboran menunjukkan bahwa kualitas air permukaan sungai bervariasi di lingkungan pengembangan lapangan uap panas bumi dan PLTP Hululais. Paramater kualitas air kritis (critical level) yaitu TSS, $\mathrm{BOD}_{5}, \mathrm{COD}, \mathrm{pH}$, koliform total, boron dan seng yang melebihi bakuutu PP Nomor 82 Tahun 2001 tentang Pengelolaan Kualitas Air dan Pengendalian Pencermaran Air (Kelas II), terjadi pada Air Kotok Huklu, Air Koto Hilir, Air Siamang, Air WPS Cluster E dan Danau Macan II.

${ }^{8}$ Pertamina Georhermal Energy. 2018. Laporan Pelaksanaan RKL-RPL, Pengembangan Lapangan Uap Panas Bumi Hululais, Triwulan I Tahun 2018, h.I-1.

${ }^{9}$ Ibid, h. I-2 
Kualitas air tanah (sumur penduduk) di Kelurahan Taba Anyar dan Desa Danau Liang yang dilakukan paada Triwulan I Tahun 2018 tergolong layak sebagai air baku air minum. Paremeter kualitas air sumur tidak ada yang melebihi nilai bakumutu air minu yang ditetapkan dalam Permenkes Nomor 416/MENKES/PER/IX/1990. Ha ini menunjukkan air sumur tersebut memenuhi persyaratan kualitas fisik air minum yang tidak boleh berbau, tidak berasa dan tidak berwarna. ${ }^{10}$

Laporan tersebut menyarankan perlu dilakukan penanaman tanaman penutup tanah (missal kacang-kacangan/leguminocea) di bekas longsor Bukit Beriti Besar Hululais untuk mengendalikan erosi dan kadar padatan terlarut (TSS) di Air Kotok.

\section{Peraturan perundang-undangan yang berkaitan dengan Uji Kelayakan Kelas Air} Sungai di Kabupaten Lebong yang menjadi Dasar Kewenangan.

\section{a. Berdasarkan Undang-Undang Nomor 30 Tahun 2014 tentang Administrasi Pemerintahan}

Setiap tindakan dan/atau keputusan Badan/Pejabat pemerintah harus dilandaskan pada wewenang yang didasarkan pada peraturan perundang-undangan dan Asas-asas Umum Pemerintahan yang baik. Tindak pemerintahan yang dapat dilakukan dalam pengelolaan kualitas air dan pengendalian pencemaran air dapat dilakukan dengan:

1. menetapkan peraturan perundang-undangan dan produk hukum daerah;

2. menerbitkan izin;

3. melakukan tindakan nyata;

4. pembinaan dan pengawasan; dan

5. penegakan hukum.

Tindakan nyata yang dapat dilakukan oleh Pemerintah kabupaten dalam melakukan pengelolaan kualitas air meliputi:

1. Penyusunan rencana pendayagunaan air

Rencana pendayagunaan air merupakan kebijakan yang berupa perencanaan terhadap pendayagunaan air yang meliputi potensi pemanfaatan atau penggunaan air, pencadangan air berdasarkan ketersediaannya, baik kualitas maupun kuantitas dan/atau fungsi ekologis. Rencana pendayagunaan air

\footnotetext{
${ }^{10}$ Ibid, h.III-1-2.
} 
wajib memperhatikan fungsi ekologis, nilai - nilai agama serta adat istiadat yang hidup dalam masyarakat setempat.

2. Pemantauan kualitas air pada sumber-sumber air

Bupati berwenang melakukan pemantauan kualitas air pada sumber air yang ada di daerah sekurang-kurangnya 6 (enam) bulan sekali.

3. Menetapkan status mutu air

Berdasarkan pemantauan kualitas air pada sumber-sumbernya Bupati berwenang menetapkan status mutu air, yang terdiri dari:

a. Kondisi cemar, apabila mutu air tidak memenuhi baku mutu air;

b. Kondisi baik, apabila mutu air memenuhi baku mutu air.

Dalam hal status mutu air menunjukkan kondisi cemar, maka Bupati melakukan upaya penanggulangan pencemaran dan pemulihan kualitas air. Dalam hal kondisi tercemar diakibatkan oleh perbuatan kegiatan dan/atau usaha maka upaya penanggulangan pencemaran dan pemulihan kualitas air dilakukan oleh pihak pencemar.

4. Menetapkan kelas air

Bupati berwenang untuk menetapkan kelas air sesuai dengan klasifikasi mutu air berdasarkan Peraturan Perundang-undangan. Penetapan kelas air yang ditetapkan dalam Keputusan Bupati. Dalam melakukan pengendalian pencemaran air Bupati dapat menetapkan kebijakan berupa:

a. Inventarisasi dan identifikasi sumber pencemar air

Melakukan inventarisasi, identifikasi, rekapitulasi dan analisis sumber pencemar air skala kabupaten dan wajib dilaporkan kepada Gubernur. Pemutakhirannya wajib dilakukan 1 (satu) kali dalam 1 (satu) tahun.

b. Penetapan daya tampung beban pencemaran air

Menetapkan daya tampung beban pencemar untuk sungai, muara, danau, waduk, dan/atau situ yang berada dalam wilayah kabupaten/kota, dengan menimbangkan:

a) kondisi hidrologi dan morfologi sumber air termasuk status mutu dan/atau status trofik sumber air yang ditetapkan daya tampung beban pencemarannya;

b) baku mutu air untuk sungai dan muara;

c) baku mutu air serta kriteria status trofik air untuk situ, danau, dan waduk; dan 
d) beban pencemaran pada masing-masing sumber pencemar air.

\section{b. Undang-Undang Nomor 32 Tahun 2009 tentang Pengelolaan Lingkungan Hidup (Lembaran Negara Republik Indonesia Tahun 2009 Nomor 140, Tambahan Lembaran Negara Republik Indonesia Nomor 5059).}

Air merupakan salah satu media lingkungan hidup, pengelolaan kualitas air dan pencegahan pencemaran air yang dilakukan dengan uji kelayakan kelas air sungai merupakan salah satu bentuk perlindungan dan pengelolaan lingkungan hidup. Uji kelayakan kelas air sungai memiliki keterkaitan dengan aspek-aspek yang diatur dalam UUPLH, diantaranya baku mutu lingkungan hidup, yaitu ukuran batas atau kadar makhluk hidup, zat, energi, atau komponen yang ada atau harus ada dan/atau unsur pencemar yang ditenggang keberadaannya dalam suatu sumber daya tertentu sebagai unsur lingkungan hidup (Pasal 1 angka 13). Pencemaran lingkungan hidup dan apasaja kriteria baku kerusakan lingkungan diatur dalam Undnag-undang ini.

UUPLH memberi kewenangan kepada Pemerintah Daerah (termasuk dalam hal ini Kabupaten Lebong), yaitu wewenang melakukan pengendalian pencemaran dan/atau kerusakan lingkungan hidup yang meliputi upaya a. pencegahan; b. penanggulangan; dan c. pemulihan (Pasal 13 ayat (3). Dalam melakukan pencegahan, maka menurut Pasal 14 terdapat beberapa instrumen yang diperlukan. Sedangkam tolok ukur meliputi antara lain a. baku mutu air; b. baku mutu air limbah; c. baku mutu air laut. Setiap orang diperbolehkan untuk membuang limbah ke media lingkungan hidup dengan persyaratan: a. memenuhi baku mutu lingkungan hidup; dan b. mendapat izin dari Menteri, gubernur, atau bupati/walikota sesuai dengan kewenangannya (Pasal 20).

c. Undang-Undang Nomor 36 Tahun 2009 tentang Kesehatan (Lembaran Negara Republik Indonesia Tahun 2009 Nomor 144, Tambahan Lembaran Negara Republik Indonesia Nomor 5063)

Ketentuan Undang-Undang Kesehatan yang terkait dengan uji kelayakan kelas air sungai dalam arti baku mutu air, terdapat dalam bab kesehatan lingkungan, sebagaimana diatur dalam Pasal 163 berbunyi:

(1) Pemerintah, pemerintah daerah dan masyarakat menjamin ketersediaan lingkungan yang sehat dan tidak mempunyai risiko buruk bagi kesehatan.

(2) Lingkungan sehat sebagaimana dimaksud pada ayat (1) mencakup lingkungan permukiman, tempat kerja, tempat rekreasi, serta tempat dan fasilitas umum. 
(3) Lingkungan sehat sebagaimana dimaksud pada ayat (2) bebas dari unsurunsur yang menimbulkan gangguan kesehatan, antara lain:

a. limbah cair;

b. limbah padat;

c. limbah gas;

d. sampah yang tidak diproses sesuai dengan persyaratan yang ditetapkan pemerintah;

e. binatang pembawa penyakit;

f. zat kimia yang berbahaya;

g. kebisingan yang melebihi ambang batas;

h. radiasi sinar pengion dan non pengion;

i. air yang tercemar;

j. udara yang tercemar; dan

k. makanan yang terkontaminasi.

d. Undang-Undang Nomor 23 Tahun 2014 tentang Pemerintah Daerah (Lembaran Negara Republik Indonesia Tahun 2014 Nomor 244, Tambahan Lembaran Negara Republik Indonesia Nomor 5587) sebagaimana telah beberapa kali diubah, terakhir dangan Undang-Undang Nomor 9 Tahun 2015 tentang Perubahan Kedua Atas Undang-Undang Nomor 23 Tahun 2014 tentang Pemerintah Daerah (Lembaran Negara Republik Indonesia Tahun 2015 Nomor 58, Tambahan Lembaran Negara Republik Indonesia Nomor 5679)

Pasal 12 ayat (2) Urusan Pemerintahan Wajib yang tidak berkaitan dengan Pelayanan Dasar sebagaimana dimaksud dalam Pasal 11 ayat (2) meliputi antara lain pada huruf e. lingkungan hidup. Selanjutnya pada Lampiran C. Pembagian Urusan Pemerintahan Bidang Pekerjaan Umum dan Penataan Ruang, Sub Urusan Sumber Daya Air (SDA) wewenang kabupaten/kota a. Pengelolaan SDA dan bangunan pengaman pantai pada wilayah sungai dalam 1 (satu) Daerah kabupaten/kota. b. Pengembangan dan pengelolaan sistem irigasi primer dan sekunder pada daerah irigasi yang luasnya kurang dari 1000 ha dalam 1 (satu) Daerah kabupaten/kota.

Kewenangan pada Sub urusan air limbah,meliputi Pengelolaan dan pengembangan sistem air limbah domestik dalam Daerah kabupaten/kota. Kewenangan bidang Sub urusan drainase meliputi Pengelolaan dan pengembangan system drainase yang terhubung langsung dengan sungai dalam Daerah. Pada Lampiran huruf K. Pembagian Urusan Pemerintahan Bidang Lingkungan Hidup, Sub Urusan Pengendalian Pencemaran dan/atau Kerusakan Lingkungan Hidup, wewenang kabupaten/kota 
meliputi Pencegahan, penanggulangan dan pemulihan pencemaran dan/atau kerusakan lingkungan hidup dalam Daerah kabupaten/kota. Wewenang pada Sub urusan Pembinaan dan pengawasan terhadap izin lingkungan dan izin perlindungan dan pengelolaan lingkungan hidup (PPLH), meliputi Pembinaan dan pengawasan terhadap usaha dan/atau kegiatan yang izin lingkungan dan izin PPLH diterbitkan oleh Pemerintah Daerah kabupaten/kota.

Dengan demikian ada kewajiban bagi pemerintah, Pemerintah Provinsi dan Pemerintah Kabupaten/Kota untuk melakukan berbagai tindak pemerintahan dan kebijakan untuk melakukan perlindungan dan pengelolaan lingkungan hidup guna memenuhi hak masyarakat untuk memperoleh lingkungan hidup yang baik dan sehat, diantaranya dengan mengatur sumber daya air di daerah kabupaten.

e. Peraturan Pemerintah Nomor 82 Tahun 2001 tentang Pengelolaan Kualitas Air dan Pengendalian Pencemaran Air (Lembaran Negara Republik Indonesia Tahun 2011 Nomor 153, Tambahan Lembaran Negara Republik Indonesia Nomor 4161)

Pasal 9 ayat (1) menentukan bahwa "Penetapan kelas air sebagaimana dimaksud dalam Pasal 8 pada huruf c. sumber air yang berada dalam wilayah Kabupaten/Kota ditetapkan dengan Peraturan Daerah Kabupaten/Kota.

Pada ayat (2) ditentukan "Penetapan kelas air sebagaimana dimaksud dalam ayat (1) diajukan berdasarkan pada hasil pengkajian yang dilakukan oleh Pemerintah, Pemerintah Provinsi, dan atau Pemerintah Kabupaten/Kota berdasarkan wewenangnya sesuai dengan peraturan perundang-undangan yang berlaku. Pada ayat (4) dinyatakan "Pedoman pengkajian untuk menetapkan kelas air sebagaimana dimaksud dalam ayat (2) ditetapkan oleh Menteri.

Pasal 13 ayat (1) menentukan bahwa "Pemantauan kualitas air pada: a. sumber air yang berada dalam wilayah Kabupaten/Kota dilaksanakan oleh Pemerintah Kabupaten/Kota. Ayat (3) menentukan "Pemantauan kualitas air sebagaimana dimaksud dalam ayat (1) dilakukan sekurang-kurangnya 6 (enam) bulan sekali. Ayat (4) Hasil pemantauan sebagaimana dimaksud dalam ayat (1) huruf a dan huruf b, disampaikan kepada Menteri. Ayat (5) Mekanisme dan prosedur pemantauan kualitas air ditetapkan lebih lanjut dengan Keputusan Menteri.

Wewenang melakukan Pengendalian Pencemaran Air diatur dalam Pasal 18 ayat (3) yang berbunyi "Pemerintah Kabupaten/Kota melakukan pengendalian pencemaran air pada sumber air yang berada pada Kabupaten/Kota." 
Jelaslah bahwa Peraturan Pemerintah Nomor 82 Tahun 2001 merupakan dasar hukum yang memberikan kewenangan kepada Pemerintah Kabupaten/Kota dalam melakukan pengelolaan kualitas air dan pengendalian pencemaran air sesuai dengan kewenangan kewilayahannya.

\section{f. Peraturan Pemerintah Nomor 42 Tahun 2008 tentang Pengelolaan Sumber Daya Air (Lembaran Negara Republik Indonesia Tahun 2008 Nomor 82, Tambahan Lembaran Negara Republik Indonesia Nomor 4858)}

Selanjutnya mengenai kebijakan pengelolaan air diatur dalam Pasal 8 berbunyi: (1) Kebijakan pengelolaan sumber daya air pada tingkat provinsi atau kabupaten/kota dapat ditetapkan sebagai kebijakan tersendiri atau terintegrasi ke dalam kebijakan pembangunan provinsi atau kabupaten/kota yang bersangkutan; (2) Kebijakan pengelolaan sumber daya air yang ditetapkan secara tersendiri sebagaimana dimaksud pada ayat (1) menjadi salah satu acuan dalam penyusunan, peninjauan kembali, dan/atau penyempurnaan kebijakan pembangunan di wilayah provinsi atau kabupaten/kota; (3) Dalam hal kebijakan pengelolaan sumber daya air diintegrasikan ke dalam kebijakan pembangunan provinsi atau kabupaten/kota, penyusunan kebijakan pembangunan provinsi atau kabupaten/kota harus mempertimbangkan kondisi sumber daya air.

Tentang kriteria dan tata cara penetapan wilayah sungai diatur dalam Pasal 9 yang berbunyi:

Wilayah sungai sebagaimana dimaksud dalam Pasal 4 ayat (1) huruf b ditetapkan sebagai:
a. wilayah sungai dalam satu kabupaten/kota;
b. wilayah sungai lintas kabupaten/kota;
c. wilayah sungai lintas provinsi;
d. wilayah sungai lintas negara; dan
e. wilayah sungai strategis nasional.

Pasal 10 mengatur bahwa:

Wilayah sungai sebagaimana dimaksud dalam Pasal 9 ditentukan berdasarkan:

a. efektivitas pengelolaan sumber daya air dengan kriteria:

1) dapat memenuhi kebutuhan konservasi sumber daya air dan pendayagunaan sumber daya air; dan/atau

2) telah tersedianya prasarana sumber daya air yang menghubungkan daerah aliran sungai yang satu dengan daerah aliran sungai yang lain.

b. efisiensi pengelolaan sumber daya air dengan kriteria rentang kendali pengelolaan sumber daya air; dan

c. keseimbangan pengelolaan sumber daya air pada daerah aliran sungai basah dan daerah aliran sungai kering dengan kriteria tercukupinya hak setiap orang 
untuk mendapatkan air guna memenuhi kehidupan yang sehat, bersih, dan produktif.

Pasal 12 ayat (1) menentukan: "Pemerintah provinsi dan/atau pemerintah kabupaten/kota atas inisiatif sendiri atau permintaan Pemerintah menyampaikan usulan penetapan wilayah sungai kepada Menteri setelah mendapat pertimbangan dewan atau wadah koordinasi pengelolaan sumber daya air di daerah".

Pasal 13 menentukan "Penetapan wilayah sungai dapat ditinjau kembali apabila ada perubahan fisik dan/atau nonfisik di wilayah sungai yang bersangkutan yang berdasarkan kriteria sebagaimana dimaksud dalam Pasal 10 dan Pasal 11 mengakibatkan perubahan batas wilayah sungai dan/atau perubahan kelompok wilayah sungai".

Pasal 17 berbunyi:

(1) Rancangan pola pengelolaan sumber daya air pada wilayah sungai dalam satu kabupaten/kota dirumuskan oleh wadah koordinasi pengelolaan sumber daya air pada wilayah sungai dalam satu kabupaten/kota.

(2) Dinas pada tingkat kabupaten/kota membantu wadah koordinasi pengelolaan sumber daya air pada wilayah sungai dalam satu kabupaten/kota dalam penyusunan rancangan pola pengelolaan sumber daya air sebagaimana dimaksud pada ayat (1).

(3) Penyusunan rancangan pola pengelolaan sumber daya air sebagaimana dimaksud pada ayat (2) harus dilakukan melalui konsultasi publik dengan instansi teknis dan unsur masyarakat terkait.

(4) Rancangan pola pengelolaan sumber daya air yang telah dirumuskan oleh wadah koordinasi pengelolaan sumber daya air pada wilayah sungai dalam satu kabupaten/kota diserahkan kepada bupati/walikota untuk ditetapkan sebagai pola pengelolaan sumber daya air wilayah sungai dalam satu kabupaten/kota.

(5) Dalam hal wadah koordinasi pengelolaan sumber daya air pada wilayah sungai dalam satu kabupaten/kota tidak atau belum terbentuk, perumusan rancangan pola pengelolaan sumber daya air sebagaimana dimaksud pada ayat (1) dilakukan oleh wadah koordinasi pengelolaan sumber daya air kabupaten/kota.

(6) Dalam hal wadah koordinasi pengelolaan sumber daya air kabupaten/kota yang bersangkutan tidak atau belum terbentuk, rancangan pola pengelolaan sumber daya air yang disusun oleh Dinas, setelah melalui konsultasi publik dengan instansi teknis dan unsur masyarakat terkait, disampaikan kepada bupati/walikota untuk ditetapkan menjadi pola pengelolaan sumber daya air wilayah sungai dalam satu kabupaten/kota.

Pasal 22 berbunyi:

(1) Pola pengelolaan sumber daya air yang sudah ditetapkan dapat ditinjau dan dievaluasi paling singkat setiap 5 (lima) tahun sekali.

(2) Hasil peninjauan dan evaluasi sebagaimana dimaksud pada ayat (1) menjadi dasar pertimbangan bagi penyempurnaan pola pengelolaan sumber daya air.

Penyusunan dan Penetapan Rencana Pengelolaan Sumber Daya Air diatur dalam Pasal 27 yang berbunyi: 
(1) Untuk wilayah sungai dalam satu kabupaten/kota, pemilihan strategi dilakukan oleh wadah koordinasi pengelolaan sumber daya air pada wilayah sungai dalam satu kabupaten/kota yang bersangkutan.

(2) Dalam hal wadah koordinasi pengelolaan sumber daya air pada wilayah sungai dalam satu kabupaten/kota tidak atau belum terbentuk, pemilihan strategi pengelolaan sumber daya air dilakukan oleh wadah koordinasi pengelolaan sumber daya air kabupaten/kota.

(3) Dalam hal wadah koordinasi pengelolaan sumber daya air kabupaten/kota sebagaimana dimaksud pada ayat (2) tidak atau belum terbentuk, pemilihan strategi pengelolaan sumber daya air dilakukan oleh bupati/walikota dengan melibatkan instansi terkait.

Pasal 32 berbunyi:

Rancangan rencana pengelolaan sumber daya air pada setiap wilayah sungai disusun untuk jangka waktu 20 (dua puluh) tahun.

Pasal 33 berbunyi:

(1) Rancangan rencana pengelolaan sumber daya air pada wilayah sungai dalam satu kabupaten/kota disusun oleh Dinas pada tingkat kabupaten/kota melalui konsultasi publik dengan instansi teknis dan unsur masyarakat terkait.

(2) Rancangan rencana pengelolaan sumber daya air sebagaimana dimaksud pada ayat (1) dibahas dalam wadah koordinasi pengelolaan sumber daya air pada wilayah sungai dalam satu kabupaten/kota untuk mendapatkan pertimbangan.

(3) Rancangan rencana pengelolaan sumber daya air yang telah mendapatkan pertimbangan dari wadah koordinasi pengelolaan sumber daya air pada wilayah sungai dalam satu kabupaten/kota sebagaimana dimaksud pada ayat (2) disampaikan oleh Dinas pada tingkat kabupaten/kota kepada bupati/walikota untuk ditetapkan menjadi rencana pengelolaan sumber daya air wilayah sungai dalam satu kabupaten/kota.

(4) Dalam hal wadah koordinasi pengelolaan sumber daya air pada wilayah sungai dalam satu kabupaten/kota tidak atau belum terbentuk, rancangan rencana pengelolaan sumber daya air dibahas oleh wadah koordinasi pengelolaan sumber daya air kabupaten/kota.

(5) Dalam hal wadah koordinasi pengelolaan sumber daya air kabupaten/kota yang bersangkutan tidak atau belum terbentuk, bupati/walikota menetapkan rencana pengelolaan sumber daya air sesuai dengan rancangan sebagaimana dimaksud pada ayat (1).

Pengelolaan Kualitas Air dan Pengendalian Pencemaran Air diatur dalam Pasal 64 yang berbunyi:

(1) Pengelolaan kualitas air dan pengendalian pencemaran air ditujukan untuk mempertahankan dan memulihkan kualitas air yang masuk dan yang berada pada sumbersumber air.

(2) Pengelolaan kualitas air dilakukan dengan cara memperbaiki kualitas air pada sumber air dan prasarana sumber daya air.

(3) Perbaikan kualitas air pada sumber air dan prasarana sumber daya air sebagaimana dimaksud pada ayat (2) dilakukan oleh Pemerintah atau pemerintah daerah sesuai dengan wewenang dan tanggung jawabnya melalui: 

a. penetapan kelas air dan baku mutu air pada sumber air;
b. pemantauan kualitas air pada sumber air;
c. pengendalian kerusakan sumber air;
d. penanggulangan pencemaran air pada sumber air; dan
e. perbaikan fungsi lingkungan untuk mengendalikan kualitas air.

(4) Perbaikan kualitas air pada sumber air dan prasarana sumber daya air dapat dilakukan melalui kegiatan, antara lain:

a. aerasi pada sumber air dan melalui prasarana sumber daya air;

b. pemanfaatan organisme dan mikroorganisme yang dapat menyerap bahan pencemar pada sumber air dan prasarana sumber daya air;

c. pembuatan sumur infiltrasi di sepanjang pantai untuk memperbaiki kualitas air tanah yang telah terkena intrusi air asin; dan

d. penggelontoran sumber air dalam keadaan yang mendesak.

(5) Pengendalian pencemaran air dilakukan dengan cara mencegah masuknya pencemar pada sumber air dan prasarana sumber daya air.

(6) Ketentuan mengenai pengelolaan kualitas air dan pengendalian pencemaran air diatur dalam peraturan pemerintah tentang pengelolaan kualitas air dan pengendalian pencemaran air.

Kemudian dalam Pasal 117 ayat (1) bahwa "Pemerintah dan pemerintah daerah bertanggung jawab menyediakan anggaran untuk biaya pengelolaan sumber daya air sesuai dengan wewenang dan tanggung jawabnya".

\section{g. Peraturan Pemerintah Nomor 38 Tahun 2011 tentang Sungai (Lembaran Negara Republik Indonesia Tahun 2011 Nomor 74, Tambahan Lembaran Negara Republik Indonesia Nomor 5230)}

Sungai dikuasai oleh negara dan merupakan kekayaan negara. Pengelolaan sungai dilakukan secara menyeluruh, terpadu, dan berwawasan lingkungan dengan tujuan untuk mewujudkan kemanfaatan fungsi sungai yang berkelanjutan. Pengelolaan sungai sebagaimana dilakukan oleh Pemerintah, pemerintah provinsi, atau pemerintah kabupaten/kota sesuai dengan kewenangannya. Pengelolaan sungai harus dengan izin. Pembagian wewenang di bidang perizinan pemanfaatan sungai diatur dalam Pasal 58. Kewajiban pemegang izin diatur dalam Pasal 59. Sanksi bagi pemegang izin diatur pada Pasal 60.

\section{h. Peraturan Daerah Provinsi Bengkulu Nomor 6 Tahun 2005 tentang Penetapan Baku Mutu Air Sungai dan Kelas Air Sungai Lintas Kabuaten/Kota dalam Provinsi Bengkulu.}

Perda ini merupakan pelaksanaan atas amanat Pasal 9 ayat (1) huruf b Peraturan Pemerintah Nomor 82 Tahun 2001 tentang Pengelolaan Kualitas Air dan Pengendalian Pencemaran Air Dalam Peraturan Daerah, yang mendelegasikan kewenangan kepada pemerintah provinsi untuk menetapkan klasifikasi air yang berada dalam dua atau lebih wilayah Kabupaten/Kota. Dalam Perda tersebut air sungai yang bersifat lintas 
kabupaten/kota sehingga penetapan kelas airnya menjadi wewenang provinsi yaitu air ketahun dan air sebelat. Di Kabupaten Lebong, ada 1 sungai yang bersifat lintas kabupaten/kota, yaitu air sungai Ketahun beserta anak-anak sungainya, sedangkan 35 air sungai lainnya merupakan sungai yang berada dalam Kabupaten Lebong dan menjadi wewenang Pemerintah Daerah Kabupaten Lebong.

\section{i. Peraturan Daerah Kabupaten Lebong Nomor 14 Tahun 2012 Tentang Rencana Tata Ruang Wilayah (RTRW) Kabupaten Lebong Tahun 2016-2036}

RTRW Kabupaten Lebong menetapkan rencana struktur ruang dan pola pemanfaatan ruang kabupaten sebagai arahan dalam peruntukan kawasan di wilayah Kabupaten Lebong. Sistem jaringan sumber daya air:

1) Sungai Ketahun berhulu di Kecamatan Topos dan bermuara di Samudera Hindia dengan Melintasi Kabupaten Bengkulu Utara

2) Sungai Seblat berhulu di Kecamatan Pinang Belapis dan bermuara di Samudera Hindia dengan Melintasi Kabupaten Bengkulu Utara.

Sistem jaringan energi:

1) Pembangkit Listrik Tenaga Air (PLTA), terdapat di Danau Tes di Kecamatan Lebong Selatan meliputi PLTA Danau Tes

2) pembangkit listrik tenaga panas bumi, terdapat di Kecamatan Lebong Selatan

3) pengembangan kelistrikan dengan pembangkit listrik tenaga mikrohidro, terdapat pada sepanjang aliran Sungai Ketahun yang dikembangkan sebagai pengembangan pembangkit tenaga listrik

\section{j. Peraturan Daerah Kabupaten Lebong Nomor 15 Tahun 2012 tentang Rencana Pembangunan Jangka Panjang Daerah Kabupaten Lebong Tahun 2005-2025.}

Pembangunan daerah Kabupaten Lebong Tahun 2005-2025 sebagaimana tertuang dalam RPJPD Kabupaten Lebong memiliki visi: “Terwujudnya Kabupaten Lebong yang Agamis, Sejahtera, Adil, Aman, Unggul, Berwawasan Lingkungan, dan Bermartabat”. Upaya untuk mencapai visi tersebut maka pembangunan daerah diarahkan pada 4 (empat) tujuan kondisi masyarakat yang harus terwujud, yaitu: (1) masyarakat yang beriman, bertakwa, (2) masyarakat yang adil, aman, dan unggul, (3) masyarakat yang mandiri dan berwawasan lingkungan, dan (4) masyarakat yang sejahtera dan bermartabat. 
Tujuan tersebut dijabarkan ke dalam misi ke-4 (empat), yaitu mewujudkan pemanfaatan sumber daya alam dan lingkungan yang berkelanjutan. Misi ke empat ini ditujukan untuk mengoptimalkan pemanfaatan sumber daya alam dan lingkungan hidup yang berkesinambungan, khususnya pengembangan potensi sumber daya alam diantaranya panas bumi (geothermal) dan air dalam meningkatkan kapasitas sumber daya energi bagi masyarakat.

Hal ini sejalan dengan perancangan perwujudan Kabupaten Lebong sebagai Kabupaten Konservasi dan Lumbung Energi agar lebih memberikan arah pembangunan dengan paradigma khusus yaitu pembangunan yang memprioritaskan pertimbangan lingkungan untuk mencapai kebutuhan dan kesejahteraan masyarakat.

Pengaturan kelas air sungai Kabupaten Lebong yang akan diatur dalam Raperda $a$ quo menjadi instrumen dalam mewujudkan masyarakat yang mandiri dan berwawasan lingkungan dan misi mengoptimalkan pemanfaatan sumber daya alam dan lingkungan hidup yang berkesinambungan, khususnya pengembangan potensi sumber daya alam diantaranya air sungai di Kabupaten Lebong.

\section{k. Peraturan Daerah Kabupaten Lebong Nomor 8 Tahun 2016 tentang Rencana Pembangunan Jangka Menengah Daerah (RPJMD) Kabupaten Lebong Tahun 2016-2021.}

Salah satu misinya yaitu mewujudkan pengelolaan sumber daya alam dan komoditas unggulan yang berdaya saing serta berwawasan lingkungan. Air merupakan salah satu sumber daya lingkungan yang sangat dibutuhkan untuk kelangsungan hidup umat manusia, sehingga perlu dilakukan tindak pemerintahan untuk melakukan upaya pengelolaan kualitas air dan pengendalian pencemaran air melalui Uji Kelayakan Kelas Air Sungai. Wewenang melakukan Uji Kelayakan Kelas Air Sungai yang dimaksudkan untuk menjamin kualitas air dan pengendalian pencemaran air yang dilakukan oleh Pemerintah Kabupaten Lebong tidak hanya didasarkan pada Undang-Undang Nomor 23 Tahun 2014, tetapi juga didasarkan pada Undang-Undang Nomor 32 Tahun 2009 tentang Perlindungan dan Pengelolaan Lingkungan Hidup, serta Peraturan Pemerintah Nomor 82 Tahun 2001 tentang Pengelolaan Kualitas Air berupa 1) penyusunan rencana pendayagunaan air; 2) pemantauan kualitas air pada sumber-sumber air; 3) menetapkan status mutu air; dan 4) menetapkan kelas air.

Pemerintah Kabupaten Lebong membentuk Peraturan Daerah tentang Uji Kelayakan Kelas Air Sungai Di Kabupaten Lebong merupakan implementasi dari 
peranan negara sebagaimana dikatakan oleh W. Friedmann yang membagi fungsi negara ke dalam dua tipe, yakni: pertama, Fungsi negara sebagai penyedia (provider), fungsi ini dikaitan dengan konsep kesejahteraan sosial (welfare state). Negara bertanggung jawab menyediakan sarana dan prasarana untuk pemenuhan kebutuhan pokok masyarakat dalam rangka menjamin standar kehidupan bagi semua orang, dalam hal ini menyediakan sarana untuk terpenuhinya kebutuhan ketersediaan air yang berkualitas bagi masyarakat Kabupaten Lebong. Dalam memenuhi hak masyarakat untuk memperoleh lingkungan yang baik dan sehat, maka perlindungan dan pengelolaan lingkungan harus dilakukan oleh semua pihak, baik pemerintah, pemerintah daerah dan masyarakat.

\section{Penutup}

Landasan kewenangan Pemerintah Daerah Kabupaten Lebong dalam mengatur uji kelayakan kelas air sungai di Kabupaten Lebong didasarkan atas kewenangan dalam melaksanakan urusan pemerintahan konkuren bidang lingkungan hidup yang diatur dalam Pasal 12 Undang-Undang Nomor 23 Tahun 2014 tentang Pemerintahan Daerah, dan amanat Undang-Undang Nomor 32 Tahun 2009 tentang Perlindungan dan Pengelolaan Lingkungan Hidup, serta amanat Peraturan Pemerintah Nomor 82 Tahun 2001 tentang Pengelolaan Kualitas Air yaitu amanat melakukan penyusunan rencana pendayagunaan air; pemantauan kualitas air pada sumber-sumber air; menetapkan status mutu air; dan menetapkan kelas air.

Permasalahan yang dihadapi Pemerintah Daerah Kabupaten Lebong dalam aktivitas pengelolaan sumber daya air sungai yaitu: (a) belum adanya payung hukum berupa Peraturan Daerah yang dapat dijadikan pedoman dalam melakukan uji kelayakan kelas air sungai di Kabupaten Lebong; (b) keterbatasan sumber daya, baik sumber daya manusia maupun teknologi dan peralatan yang dimiliki Dinas Lingkungan Hidup Kabupaten Lebong; (c) terbatasnya dukungan anggaran untuk melakukan pemantauan 33 sungai besar dan kecil yang ada dalam wilayah Kabupaten Lebong; (d) penyusunan Rancangan Peraturan Daerah tentang Uji Kelayakan Kelas Air Sungai dapat dilaksanakan secara baik, maka diperlukan mekanisme dan prosedur yang transparan serta dukungan pembiayaan yang cukup dari APBD Kabupaten Lebong. Kebijakan pengelolaan kualitas air dan pengendalian pencemaran air harus didukung oleh sarana dan prasarana serta kemauan dan kemampuan seluruh Organisasi Perangkat Daerah yang optimal, baik dari segi Sumber Daya Manusia dan sarana teknis yang memadai. 


\section{Buku}

\section{Daftar Pustaka}

A.Hamid S.Attamimi. (1993). Pancasila Cita Hukum dalam Kehidupan Hukum Bangsa Indonesia. Artikel dalam Kumpulan Tulisan Pancasila Sebagai Ideologi, Jakarta: BP-7 Pusat.

A. Nontji. (1987). Laut Nusantara. Jakarta: Djambatan.

Bahder Johan Nasution. (2008). Metode Penelitian Ilmu Hukum. Bandung: Mandar Maju.

C. Asdak. (2010). Hidrologi dan Pengelolaan Daerah Aliran Sungai. Yogyakarta: Gajahmada University Press.

Badan Pusat Statistik. (2017). Kabupaten Lebong dalam Angka 2017.

Depdikbud RI. (1995). Kamus Besar Bahasa Indonesia. Jakarta: PN.Balai Pustaka.

Diyah Agustiningsih. (2012). Kajian Kualitas Air Sungai Blukar Kabupaten Kendal Dalam Upaya Pengendalian Pencemaran Air Sungai. Tesis Magister Ilmu Lingkungan. Universitas Diponegoro. Semarang.

E. Arianto.(2008). Parameter fisika dan kimia perairan. Diunduh, 17 November 2018, dari ErikArianto Wordpress: https://erikarianto.wordpress.com/2008/01/10/parameterfisikadan-kimia-perairan.

G. Alaerts., \& S.Santika. (1987). Metoda Penelitian Air. Surabaya: Usaha Nasional.

I.C.Van der Vlies. (2005). Handboek Wetgeving, alih bahasa Linus Dolujawa, Buku Pegangan Perancang Peraturan Perundang-undangan. Jakarta: Departemen Hukum dan HAM RI.5

KM. Kordi. (2004). Penanggulangan Hama dan Penyakit Ikan. Jakarta: PT. Rineka Cipta.

M.G. Kordi \& B.T.Andi. (2009). Pengelolaan Kualitas Air dalam Budidaya Perairan. Jakarta: PT. Rineka Cipta .

Mahendra Putra Kurnia, et.all. (2007). Pedoman Naskah Akademik Perda Partisipatif. Jakarta: Total Media.

Maria Farida Indrati S. (2007). Ilmu Perundang-undangan, Jenis, Fungsi dan Materi Muatan. Yogyakarta: Kanisius.

Maria Farida Indrati S. (2007). Ilmu Perundang-undangan, Proses dan Teknik Pembentukannya. Yogyakarta: Kanisius.

Masduqi. (2009). Keberlanjutan Sistem Penyediaan Air Bersih Perpipaan di Perdesaan. Disertasi Doktor. Surabaya, Jawa Timur, Indonesia: Institut Teknologi Sepuluh Nopember Surabaya. 
Montesquieu. (1977). The Spirit of Laws, University of California Press, diterjemahkan oleh M. Khoiril Anam, Dasar-Dasar Ilmu Hukum dan Ilmu Politik, Bandung: Nusamedia.

R.A. Islamy. (2012). Perairan dan Lingkungan Sekitar. Diunduh 17 November 2018, dari Dhariyan Blogspot: http://dhariyan.blogspot.com/2012/12/perbedaan-bod-dan-cod.html

Soeratmo, F.G. (1988). Analisis Mengenai Dampak Lingkngan. Yogyakarta: Gama University Press.

Otto Soemarwoto. (1988). Analisis Dampak Lingkungan. Yogyakarta: Gama University Press.

PT. Jambi Resources. (2017). Laporan Pelaksanaan Izin Lingkungan Kegiatan Penambangan Batubara Triwulan I Januari-Maret 2017. KP.KW 001 K.L.08 Desa Ketenong II, Keamatan Pidang Belapis, Lebong Provinsi Bengkulu.

PT. PLN (Persero) Pembangitan Sumbagsel Unit PLA TES. (2018). Rencana Pegelolan Lingkungan dan Rencana Pemantauan Lingkungan (RKL-RPL) Laporan Triwulan I Maret.

PT. Pertamina Geothermal Energy. (2018). Laporan Implementasi RKL-RPL Pengembangan Lapangan Uap Panas dan PLTP Hululais di Kecamatan Lebong Tengah dan Lebong Selatan Kabupaten Lebong, Periode Triwulan I.

PT. Tansri Madjid Energi (Gold Mining Project). (2018). Laporan Pelaksanaan Pengelolaan Lingkungan Hidup Triwulan I, Maret.

Yuliandri. (2007). Asas-Asas Pembentukan Peraturan Perundang-undangan Yang Baik Dalam Rangka Pembuatan Undang-Undang Yang Berkelanjutan. Jakarta: Rineka Cipta. 